\title{
COMPULSORY COMPETITIVE TENDERING IN BRITAIN
}

\author{
Lucky Aminarko dan Simon Delay \\ Fakultas Ekonomi \\ Universitas Andalas Padang
}

\begin{abstract}
Abstrak
Upaya-upaya untuk memperkenalkan persaingan pada pemerintah daerah di Britain dilakukan dalam bentuk Compulsory Competitive Tendering atau CCT. pelaksanaan CCT untuk pelayanan manual (manual services) diatur melalui Undang Undang Pertanahan dan Perencanaan Pemerintah Daerah tahun 1980, dan Undang Undang Pemerintah Daerah tahun 1988. Sedangkan program CCT untuk pelayanan profesional diatur melalui Undang Undang Pemerintah Daerah tahun 1992.

Artikel ini bertujuan untuk menjelaskan berbagai aspek penting dari CCT di Britain, serta mengevaluasi pelaksanaan CCT untuk pelayanan manual pada pemerintah daerah di Inggris, Skotlandia dan Wales. Pengalaman Britain dengan CCT telah memperlihatkan sejumlah dampak, seperti penghematan pelayanan antara 5,6\% dan 7\%, perubahan sikap, prosedur dan struktur pemerintah daerah, kualitas pelayanan lebih baik melalui tercapainya standar pelayanan, terpenuhinya jaminan kualitas, dan penggunaan spesifikasi kontrak yang akurat, serta peningkatan moral pekerja dan upah berdasarkan kinerja.
\end{abstract}

Key Words: British Competitive Tendering, Local Government Services, and Privatization.

\section{INTRODUCTION}

Competitive tendering is the most radical way to change the entrenched culture of public monopoly. The reasons for the introduction of market mechanism to government services are that the private sector usually provides a better service than the public sector and that shifting the emphasis from the provider to the consumer improves quality and saves money (Bulmer 1995).

Walsh (1995) explains that in the market, at least in theory, the system of prices and the exchange process allows individuals to make effective choices, which determine levels of production.

Competition in British local authorities has been promoted through compulsory competitive tendering (CCT) since 1980. Britain appears to be unique in making competitive tendering compulsory for certain local authority services. Kane (1996) argues that the compulsory nature of competition associated with British local government ensures that the policy is enshrined in a legislative framework and subject to regulation by the center.

The most extensive changes are likely to take place in the provision of local services with the imposition of CCT. CCT has been expected to give significant impact on organizational, managerial, and financial aspects of 
local authority works.

\section{COMPETITIVE TENDERING IN BRITISH LOCAL AUTHORITIES}

\section{Legislative Framework for CCT}

The legislative framework associated with CCT has evolved in three distinct phases over a period of more than a decade. The first is the Local Government Planning and Land Act 1980 which introduced CCT for a limited range of jobs mainly highways maintenance, building maintenance, and minor building work. The operations of those services were carried out by local authority Direct Labor Organizations (DLOs)

Then, in 1988 legislative framework for compulsory competition was extended via the Local Government Act 1988. The Act introduced compulsory competition for most of the manual services in local authorities, covering refuse collection, buildings cleaning, other cleaning (including street cleaning), school and welfare catering (including meals for the housebound), other catering (including staff canteens), and grounds maintenance (including parks). In 1989 the Secretary of State added the management of sports and leisure services to the list of defined activities. Local authority Direct Service Organizations (DSOs) were promoted to change DLOs' role in providing those manual services.

Finally, the legislative framework was widened via the Local Government Act 1992 which added professional services, financial and technical services. In 1993 the Leasehold Reform, Housing and Urban Development Act was introduced to allow the implementation of CCT for many of the activities of housing management.

\section{Extent of CCT}

Carnaghan and Bracewell-Milness (1993) note that CCT by 1993 still only covered about one-tenth of the spending of local authorities. Extension of competitive tendering in local authorities to professional and technical services was marginal in term of the spending involved.

INLOGOV's survey in 1993 shown that each authority lets an average of 15 contracts. The Shire Counties were found to let a lot more contracts than other types of authority since there was a tendency to break down large contracts on a geographical basis. Metropolitan Districts were more likely to let large single contracts and they let fewer contracts than other types of authority.

\section{Scope for CCT}

Local authority and other government have services that lend themselves to competition. Activities of local authorities for which competitive tendering has been suggested or practiced include manual and professional 
services.

Walsh and Davis (1993) in INLOGOV's survey discussed the defined services, such as refuse collection, street cleaning, building cleaning, catering, grounds maintenance, vehicle maintenance, and leisure management, and then reported the extension of CCT to other manual services such as cleaning of police building and maintenance of police and fire vehicles, and home-to-school transport and to direct or professional services such as the management of theatres and arts facilities; certain library support services; the provision of parking services; constructionrelated services, including architectural services, engineering services and property management services; corporate services, including administrative services, legal services, financial services, personnel services, and computing services. Other services now subject to CCT are careers advice, accountancy, residential care, home helps, computing and data processing, security, printing, fire brigades, police, civic amenity sites, pest control, dredging, and the operation of quarries and asphalt plants.

\section{Tendering Process}

There are eight stages in the tendering process, divided between clients and contractors (Audit Commission 1993). The initial stage is publication of notice. The second stage is initial expression of interest in response to notice. An average of eleven contractors expresses an interest in a contract with significant variations across service areas. Building cleaning, for example, attracts an average of twenty-one expression of interest whereas education and welfare catering attract less than six (Bulmer 1995). The third stage is to send questionnaire and outline details (make' specification available for inspection). The fourth stage is formal notification of interest (e.g. return of questionnaire). Some contractors drop out in this stage and the number of contractors is reduced to just over eight.

The fifth stage is invitation to tender (i.e. send contract documentation). In this stage, an average of about six contractors is invited to bid per contract. The sixth stage is submission of tender. An average of three contractors per contract remains to bid.

The next stage is tender evaluation and announcement of award. It can sometimes be found that an award is given without competition. Local authorities can award the contract to their in-house teams and argue that there is no private sector interest or the private sector cannot fulfill their needs. The final stage is start of contract.

Local authorities, as clients, of course, have to ensure that the contracts are clear and enforceable. Penalty clauses and performance bonds can be required of a private contractor to protect local authorities 
from inadequate performance of local services,

Improving Direct Service Organization

The evidence suggests that many local authority DSOs have been expensive and inefficient. Most DSOs cannot do the work at the same cost and quality as an outside contractor. The role of the in-house DSOs is more difficult than the external private contractor since they have very limited market. The DSOs will have to operate within the legislative framework created by the Local Government Act 1988. They face the more general limitations of local government law and practice.

The existence of efficient DSOs can be beneficial. DSOs have to adopt a commercial culture in order to survive in the increasingly competitive market. At the same time they have to serve the need of the client and those of the authority.

DSO managers must create an organization condition that has the capability to win the tender. As the Local Government Management Board (1989) suggested that four activities are needed to win tenders; preparing a business plan, developing a tender strategy, preparing the DSO for competition, and putting in a bid.

DSO will face some changes to follow a tender and win the contract. The changes in management, attitude and style, personnel and pay, vehicle and plant holdings, and depot arrangements and in overhead costs will often be needed (Audit Commission 1989).

\section{White Collar Contracting}

CCT in local government has been extended to white-collar professional services since 1992. A number of support or professional services, normally provided within local authority by directly employed staff, was subject to competition. These services include construction and property services, information technology (IT), legal services, financial services, personnel services and housing management.

The white collar CCT is carried out differently with CCT for manual services in the proportion of the work subject to be tender. This is because it is generally argued that there is a high proportion of most white collar services devoted to strategic policy making and to 'client' functions and that these functions are not suitable for contracting out (Watt 1996).

The percentages of work subject to tender are as follows; legal services $45 \%$, construction and property services $65 \%$, financial services $35 \%$, information technology services $70 \%$, personnel services $35 \%$, and housing management 95\% (Walsh 1995).

Walsh (1995) explains that the percentages have been set to take account of the amount of work that can readily be subject to tender, and to 
ensure that there is adequate provision for the internal, client-side management of the service, as well as to provide for core democratic processes. He adds that services have been examined by management consultants who suggested levels of competition on the basis of what was likely to lead to an effective market.

The implementation of white-collar CCT, according to Watt (1996), has been a lengthy process. One reason for this has been the effect of the recent Local Government Review exercise with authorities subject to reorganization generally being exempted from competition during the process of change.

As a result, competition for white-collar services in most authorities could not take place until eighteen months after reorganization.

\section{THE IMPACT OF CCT}

\section{Cultures and Organization Structure}

By introducing competition for public services, local authorities had to change their way of working and their organization structure. Fenwick (1995) notes that the qualitative changes had taken place on how local services would be organized and delivered. These changes were specifically identified as follows.

1. The compulsion to offer specified services to outside tender;

2. The obligation to keep separate trading accounts for in-house contracts, and to make a return on these;

3. The beginnings of a distinction between the local authority as client (specifying the service requirements on behalf, one might say, of those who will use the service) and the local authority as contractor (providing the specified service) and the possible tension between the two;

4. The growth of a commercial culture in the running of local authority services.

The radical changes in the attitude of local authority officers and members, and in procedures and structures took place when the local government promoted competitive market for the public services. Some local authorities have restructured their organizations as a number of services have been subjected to competition in the market place. PA Consulting Group and the Local Government Chronicle found from their survey in late 1989 that some seven in 10 authorities were found to have established separate committees for contracting activities and a clear contractor/client split. Only half the authorities said they had a corporate strategic plan, and only 36 per cent plan more than one year ahead (Carnaghan \& Bracewell-Milness, 1993, p.100). 
Functions as client and contractor had to be separated and their departments and management had to be restructured as a result of the implication of CCT. Clients have the roles of setting service standards, preparing contracts, inviting and evaluating tenders, and monitoring the work of contractors. Contractors have the roles of tendering for and carrying out the work of contracts. Clients moreover should be concerned with service standards and value for money, while contractors should be concerned with winning contracts and performing to standard and price.

Kane (1996) stated that the separation of client and contractor role is important with respect to the preoccupation of officers in CCT era. Officers on contractor side where they are part of a direct service organization (DSO) will find changes in the way that they are managed. Managers at this level may find that they have more freedom to manage resources as they see fit, which may be in contrast to other parts of the local authority.

While Norman Flynn (1993) divides the roles within organization, as a specific outcome of CCT, into a 'policy' function (deciding overall policy and resources allocation), a 'buyer' function (writing technical specifications in compliance with policies), 'contractor' functions (carrying out the work) and some central support people and mechanisms.

As a result of the separation of policy and management in public sector, the local politician can play a role as strategic policy makers and the officer's control over operational matters of service provision. The relationship between the functions within organization will also be different under these arrangements. People making overall policy do not need to have direct connection with the contractors within the organization or separately owned since expenditure of contractors operating in competition is controlled through the bidding mechanism and the payment for work done at previously agreed price. The contractors too will not need to be involved in corporate policy and the decision of corporate budget.

In Karley and Wynn's survey, it was found that in Scotland, the structural implications of CCT have led to a necessary shift from control to facilitation on the part of the traditionally dominant central service department. And the impact of CCT had significantly altered the balance of influence within their authority, away from the central department (Carnaghan \& Bracewell-Milness, 1993, p.100).

The introduction of competition would be followed by changes in structure and the way local authorities to run the services occurred would be changed when they had the requirement to keep separate trading accounts and the need to meet financial targets. Units within organization that were forced to compete become relatively independent units with their own trading accounts. Local authorities in some cases established new 
departments including all the services, which are tendered for, thus dividing the whole organization into 'buyers' and 'contractors'.

Councilors and senior officers can pay more attention on the effectiveness and quality of the services. It is important for them to consider both the type and level of services and costs because competition will cut costs and make service more efficient. These attempts to make changes in the type of services provided would inevitably lead to different working patterns, with the possibility that less staff will be involved or that existing staff will have to take on new tasks.

\section{Efficiency}

Efficiency in the use of public resources is the main purpose of CCT. It has implication for local authorities in financial terms since it reduced the operating cost of local service.

Walsh (1991) found that the main sources of savings following competitive tendering was greater productivity resulting from improved working methods and organization, and from investment in better equipment.

The study of the Audit Commission in 1993 (Bulmer 1995) suggested that CCT has brought savings averaging 7 per cent over all these services. On certain individual services, the savings have been even more dramatic; on building cleaning contracts, cost have been reduced by 20.6 per cent, in refuse collection by 12.4 per cent and grounds maintenance 10.2 per cent.

A survey of Local Government Chronicle in 1990 found that in manual services there were average savings of 5.6 per cent across a range of services, varying from 10.4 for refuse collection and 15 per cent for building cleaning to 0.2 per cent for catering (Walsh 1995).

In the INLOGOV's survey for the Department of Environment in 1993. Walsh and Davis (1993) found that average reduction in costs of 6.5 per cent for services as a result of competition, ranging from an increase in costs after competition of 62.4 per cent to a reduction in costs of 49.7 per cent. There was reduction in cost following competition in 131 (64 per cent) of the total cases, and an increase in 51 (24 per cent) cases; in 25 cases there was estimated to be no change.

The results varied widely from service to service, with higher cost reduction in refuse collection (11.3 per cent), building cleaning (12.7 per cent), and ground maintenance (10.9 per cent), while increases in costs of service occurred in street cleaning (2.6 per cent) and catering (2.8 per cent) and the other type of services such as vehicle maintenance and leisure management indicated low savings.

Dr Stephen Szymanski, doing a study for CDC research (Bulmer 
1995) found that in-house building cleaning contracts are on average 30 per cent more expensive than those awarded to private contractors.

CDC research, focused on refuse collection services in England and Wales, found that the real cost of refuse collection has fallen by over one quarter since 1984 and about half of these savings appear to have occurred after the introduction of CCT (Szymanski and Jones 1993). The findings of this research can be examined that 217 authorities in England and Wales contracting refuse collection reduced average cost by 13.4 per cent at post CCT period (1989-1992). Szynmanski in fiscal studies of 1993 (quoted in Walsh 1993) wrote that contracting has resulted in saving of at least 27 per cent in refuse collection. The CDC research also found that the cost per household of refuse collection had fallen 20 per cent a year since the introduction of CCT. Councils awarding contracts to private firms achieved savings of 23 percent; those still working with DSOs saw savings of 17 per cent.

In the case of CCT in Scottish local government Kerley and Wynn argue that the best private contractors seem able to bid for local authority services on the basis of high productivity, and yet pay wages at least comparable to those negotiated in the NJC (National Joint Council for wage bargaining). Scottish Office research indicated widespread variations in relation to costs citing ground maintenance contracts as an example where there was a saving of 32 per cent arising from one contract to an almost doubling of costs arising from another (Kane 1996).

\section{Service Quality}

CCT has radically altered the way council services are managed and delivered but local authorities have still responsibility for the quality for those services. Concerning to the quality means that the authority has to meet customer requirements. The contracting process, and the definition of services and standards it entails, can provide the vehicle for communication with consumers. Public perception and satisfaction in turn can be improved.

Even though the pursuit of service standards rarely became wholly objective of competitive tendering, service standards had generally been beneficial to be considered as the impact of competition on service quality. Local authorities had generally raised or maintained existing standards and were achieving the standards set. Their problems on service standards often occurred in parts, rather than the whole of a service.

It can be seen from the INLOGOV's survey in 1993 that 61 from 267 services adopted higher standards and 181 from 267 services adopted the same standards. This finding can be examined that $67.79 \%$ of authorities had adopted the same standard approach as operated before and $22.85 \%$ of authorities had adopted higher standards in their service specification. 
Very few authorities in this survey, only $9.36 \%$, had adopted lower standards in their service specification.

The achievement of standards will then be the most important aspect to be considered. The result of INLOGOV's survey in 1993 has shown that $89.25 \%$ of all cases had achieved the standard of the services. This percentage was gained from four different classified areas. Standards of London Boroughs services could be achieved by $90.48 \%$. Service standards of Metropolitan Districts were achieved by $86.96 \%$, while service standards of Shire Counties and Share District were attained by $89.19 \%$ and by $90.16 \%$. It was also found the only exception to general achievement of standards that building-cleaning standards in almost of all surveyed areas, except Shire District could not be achieved satisfactorily. Standards were not achieved by $50 \%$ in London Borough, by $60 \%$ in Metropolitan Districts, and $25 \%$ in Shire Counties. The standards of street cleaning were failed to be achieved well by about 25\% in Metropolitan Districts and by about 23\% in Shire Districts.

The introduction of competitive tendering has strongly influenced local authorities to deal with quality assurance of public services as well. They needed to make contract requirements on quality assurance for the contracted services and the contractors should be able to ensure that their works would be done toward certification under the relevant standard such as BS 5750 (Guide to Quality Management and Quality Systems Elements).

Local authority, as client, can use quality assurance to learn about the supplier's processes, which makes cooperation easier. It can help to raise standards and reduce the need for client contract monitoring.

In the INLOGOV's survey, it was found that the requirement for quality assurance was greatest in building cleaning (56\%), catering (65\%), and leisure management (59\%) while the lowest requirement was in refuse collection (23\%) and in street cleaning (24\%). It was also seen from this survey that there was a notably high level of interest generally in the use of BS 5750 . The major interest was in the metropolitan districts and London Boroughs with least interest being shown in shire districts (Walsh and Davis 1993). The pursuit of BS 5750 certification was useful for the DSOs since it would improve their management capacity and give them an edge in the market and it was also good for morale in some cases.

Furthermore, satisfactory quality of public services, according to Carnaghan \& Bracewell-Milness (1993), can be ensured by following three key stages; firstly, contract specifications which accurately reflect the council's objectives, then, careful selection of contractor, and finally, good monitoring throughout the term of the contract.

With CCT, contract specifications provided an opportunity for members to clarify the intended quality and to monitor its achievement and 
they reflected the council's policy objectives. Consumers too could judge contract performance. Well-defined contracts have succeeded in clarifying expectations about quality and ensuring its consistent delivery.

\section{Personnel}

The impact of CCT on personnel took place when the contractors were making changes to win contracts and its impact was carrying on after winning the contract. However, there is difference approach to personnel and industrial relations between local authority and private sector.

Moving to market mechanisms has significantly affected manual workers in activities subject to CCT. Redundancy of workers cannot be avoided when the work is contracted out to the private sector. Local Government Chronicle survey reported that the total number of redundancies from 300 councils having 160 contracts worth $£ 251$ million was 1,968 in $1988 / 89$ and in the following year there were 7,376 redundancies in 231 authorities having 476 contracts worth $£ 1,597$ (Carnaghan \& Bracewell-Milnes 1993). Walsh and Davis (1993) in their survey found staff reductions in 56 per cent of cases.

In 1990 Scottish Local Government Information Unit (SLGIU) found that 53 per cent of contracts awarded in the first two rounds of CCT (August 1989 and January 1990) resulted in job losses, 12 per cent produced cuts in pay and 17 per cent cuts in hours Carnaghan \& Bracewell-Milness 1993). SLGIU also found that of contracts won by DSOs, 26 per cent kept jobs, pay and conditions intact, but three-quarters resulted in some loss.

Workers might be moved to other sections with lower pay and inferior conditions of service. Poorer provisions will be received as a consequence of low motivation staff. Even when public sector win the tender and run the service, pay and conditions are likely to be changed to make them able to compete with private sector. Operatives of London's building maintenance DLOs in November 1990, for example, work shorter hours and have longer holidays than those working for private contractors but their bonus earnings have generally been limited to around $£ 60$ a week, giving earnings of just over $£ 200$ a week, compared with reported earnings in the private sector of $£ 300$ a week or more (Carnaghan \& BracewellMilnes (1993).

Those conditions in personnel are avoidable because of the nature of services involved. Changing some aspects of staffing is the only way to raise savings in labor-intensive services.

CCT also positively affected methods of payment and worker's morale. Performance-related pay might be preferable by DSO managers because of more general financial pressures in local authorities, and 
because of the development of performance management. Performance related pay is likely to grow as a result of the extension of competition. This method will be beneficial if it can be implemented for all levels of the DSO staff.

In 1993 INLOGOV's survey, it was found that staff's morale in DSOs was generally seen as much better than might have been expected. The increase of morale will help DSOs to improve the service and standard. It is easy to perceive that the morale of those in DSOs might be high because, by definition, they are winners. However, if a contracted service was won by external provider, the morale of DSO's staff, as loser, would be difficult to increase because they have nothing to do.

\section{CONCLUSION}

This article has examined the general aspects of competitive tendering within British local authorities and evaluated the implementation of CCT with particular emphasis upon culture and organization structure, efficiency, service quality and personnel.

Since 1988 CCT has been extended from a limited range of services to most of the manual services in local authority and it included professional services in 1992. Moving toward market mechanism made local authorities in Britain lead to bid their services to competition. Based on INLOGOV' survey in 1993, average of 15 contracts was let by each authority.

It can be identified from the discussion that CCT has affected some aspects of the services. The changes in the ways of working and structure are described as the effects of the separation of client and contractor functions and of the growth of a commercial culture in running the services. Efficiency in the services can be achieved through greater productivity resulting from improved working methods and better investment in equipment. It can be seen from some surveys that average savings varied from 5.6 per cent to 7 per cent for manual services. While quality of services can be improved through the achievement of service standards, the fulfillment of quality assurance, and the use of accurate contract specifications. Even though personnel have suffered from staff redundancy and lower pay and inferior conditions of service, but the morale was surprisingly increased and the better payment methods relating to service profit and performance will grow up as a result of Competition.

Some critical factors may need to be considered by local authorities to enable the success of CCT. Local authorities need to develop a more effective organizational infrastructure, such as information and 
accounting, if the changes are to succeed. Public organizations are likely to reproduce existing patterns of spending when they move to market mechanism. Contractors will want information about the past working conditions and costs of the service, and the way in which the contract is expected to operate.

Local authorities have to allow adequate time to prepare a tender. It is necessary for the success of CCT since a good contractor will naturally be in demand and will often be engaged in other projects. This contractor needs to assess the possibilities carefully to follow the local bid.

The commitment of the councilors and officers is also required to make the contract work. The good contractors will get involved in a wide variety of alternative proposal, formal tenders, and course of action if they are confident about the commitment of the local authority to using contractors.

A precise contract is another prerequisite for success. A contract should be considered carefully so that both client and contractor will clearly understand what is expected. Local authorities, for example, can publish the guidelines for a waste collection contract. These guidelines will describe in detail of all aspects of contract such as standards of cleanliness for vehicle, methods of payment, breach of contract, supervision by the local authority, insurance, wage agreement, fines and penalties for missed collections and so on.

\section{REFERENCES}

Adam Smith Institute (1982), 'Working With Contractors', London: The Adam Smith Institute.

Association of Metropolitan Authorities (1991), 'Competitive Tendering and the European Communities: Public Procurement, CCT and Local Services', London: AMA

Audit Commission (1989), 'Preparing for Compulsory Competition', Occasional Paper, London: HMSO.

Audit Commission (1993), 'Realizing the Benefits of Competition: The Client Role for Contracted Services', London: HMSO.

Audit Commission Bulletin (March 1995), 'Making Markets: A Review of the Audits of the Client Role for Contracted Services', London: HMSO.

Bulmer, Fiona (1995), 'Compulsory Competitive Tendering: The Continuing Challenge', London: the Conservative Political Center. 
Carnaghan, Robert and Bracewell-Milnes, Barry (1993), 'Testing the Market: Competitive Tendering for Government Services in Britain and Abroad', London: the Institute of Economic Affairs.

Clarke, Michael. And Stewart, John (1985), 'Local Government and the Public Service Orientation: Or Does a Public Service Provide for the Public', Local Government Training Board.

Cope, Stephen (1995), 'Contracting-Out in Local Government: Cutting by Privatizing', Public Policy and Administration, 10, 3, Autumn, pp. 29-44.

Davis, Howard, and Lafferty, Mike, and Page Brian (1993), 'Contracting Out Local Public Services in the Czech Republic: Lessons from British Experience'. Birmingham: INLOGOV

Fenwick, John (1995), 'Managing Local Government, London: Chapman \& Hall.

Flynn, Norman (1993), 'Public Sector Management', Hertfordshire: Harvester Wheatsheaf.

Flynn, Norman and Walsh, Kieron (1988), 'Competitive Tendering', Birmingham: INLOGOV, University of Birmingham.

Kane, Michael (1996), 'The Nature of Competition in British Local Government', Public Policy and Administration, 11, 3, Autumn, pp. 51-66.

O'Donovan Ita (1994), 'Organizational Behavior in Local Government, Essex: Longman.

Robbie, Ken and Wright, Mike (1996), 'Local Authorities, Compulsory Competitive tendering and Buy-Outs', Local Government Studies, 22, 1, Spring, pp. 127-146.

Szymanski, Stefan and Jones, Tim (1993), ' The Cost Savings from Compulsory Competitive Tendering of Refuse Collection Services: A Statistical Analysis', London: CDC Research

Walsh, Kieron (1991), 'Competitive Tendering for Local Authority Services: Initial Experiences', London: HMSO.

Walsh, Kieron (1995a), 'Competition for White-Collar Services in Local Government', Public Money and Management, April-June, pp. 11-18.

Walsh, Kieron (1995b), 'Public Services and Market Mechanism: Competition, Contracting and the New Public Management', London: Macmillan Press. 
Walsh, Kieron and Davis, Howard (1993), 'Competition and Service: The Impact of the Local Government Act 1988', London: HMSO.

Watt, Peter A. (1996), 'Compulsory Competitive Tendering for the Finance Service in Local Government', Local Government Policy Making, December, pp. 1-6. 
BIOGRAFI PENULIS

Lucky Aminarko, adalah dosen Fakultas Ekonomi Universitas Andalas Padang, la menyelesaikan S1 pada Fakultas Ekonomi Universitas Padjadjaran Bandung (1991), Postgraduate Diploma (1996) dan S2 (M.Soc.Sc) diraih dari Birmingham University, England (1999). Pada akhir tahun 2002 ini ia akan melanjutkan S3 di Institute of Public Policy and Management, Flinders University, Adelaide Australia. 